Olitzki, A. L. \& Godingen, D. (1959). J. gen. Microbiol. 20, 54-60

\title{
Investigation on Streptomycin Inhibitors with the Aid of a Streptomycin-dependent Vibrio comma
}

\author{
By A. L. OLITZKI AND DINAH GODINGER \\ Department of Bacteriology, Hebrew University-Hadassah Medical School, \\ Jerusalem, Israel
}

SUMMARY: The growth and amylase activity of a streptomycin-dependent Vibrio comma on starch agar plates was gradually decreased with decrease of the streptomycin-concentration. The concentrations of streptomycin and the streptomycinantagonizing properties of bacterial products also could be assayed by a cup plate method. The diameters of the zones of decomposed starch around the cups were proportional to the logarithms of streptomycin concentration. In the presence of a constant concentration of streptomycin they were inversely proportional to the concentration of bacterial antagonist. The following species and genera of microorganisms produced antagonists (in decreasing order of their activity): Pseudomonas sp., Proteus morganii, Clostridium botulinum, C. parabotulinum, C. welchii, C. septicum, Bacillus megaterium, B. subtilis, Rhodotorula sp., and some strains of the genera Escherichia, Shigella and Klebsiella. No inhibitory effects were observed with products of Salmonella paratyphi A and B, Serratia marcescens, Staphylococcus aureus, S. albus, Streptococcus faecalis, S. lactis, Brucella abortus, B. melitensis, Pasteurella pestis, P. pseudotuberculosis, Alkaligenes faecalis, Saccharomyces sp., Candida albicans.

Recent investigations by Olitzki \& Olitzki (1957) revealed that at low concentrations of streptomycin the amylase activity of a streptomycin-dependent strain of Vibrio comma was not developed. This inhibition was, therefore, used by them as an indicator in assaying streptomycin in liquid media. In the experiments reported this method was simplified by introducing a cup plate method which permitted the quantitative determination of concentrations of streptomycin and the antagonistic activities of different preparations against a fixed standard concentration of streptomycin.

The first investigations on antagonists of streptomycin were carried out by Lightbown (1950) who described a rapid method of demonstrating streptomycin antagonist activity in bacterial cultures. As indicator organisms Bacillus subtilis or Staphylococcus aureus were used. By incorporating both antibiotic and indicator organisms in nutrient agar, the antagonistic power of culture filtrates was assayed by a cup-plate method. The diameter of the zone of growth around the cup was proportional to the logarithm of the concentration of the antagonist, which was formed during the growth of Pseudomonas aeruginosa in chemically-defined medium and in ordinary culture medium. Lightbown (1954) isolated material produced by Pseudomonas aeruginosa which antagonized the activity of streptomycin, and which itself inhibited bacterial growth in low concentrations. The antagonist was produced by most strains of $\boldsymbol{P}$. aeruginosa under favourable conditions. Strains of Staphylococcus aureus, Escherichia coli, Serratia marcescens, Bacterium bodenheimer, 
streptococci of Lancefield's group D, Bacillus subtilis and B. pumilus did not produce similar activity. The purpose of the work reported below was to determine whether the production of streptomycin antagonists is limited to the genus Pseudomonas or shared by other micro-organisms.

\section{METHODS}

Strains employed for production of inhibitors. Forty-five bacterial strains were investigated for their ability to produce antagonists to streptomycin. The vibrios used were described in detail elsewhere (Olitzki \& Olitzki, 1955, 1957) and by Sulitzeanu \& Olitzki (1955). The indicator organism was the streptomycin-dependent strain of Vibrio comma, strain Ogawa 40.

Growth of the organisms. The aerobic and facultative anaerobic strains were grown on the surface of nutrient agar in Roux bottles from an inoculum of $2 \times 10^{9}$ bacteria suspended in $5 \mathrm{ml}$. of saline.

The anaerobes were cultivated on a medium which contained $(\%, w / v): 0 \cdot 05$, sodium mercaptoacetate; $0 \cdot 025$, cysteine; $2 \cdot 5$, enzymically-hydrolysed caseine; 0.05 , tryptophan; 0.5 , glucose; 0.0000005 , biotin; 0.0000005, thiamine; 0.00001, $p$-aminobenzoic acid; $(\%, v / v) 1 \cdot 0$, solution A; 0.1, solution B. Solution $\mathrm{A}$ contained $(\%, \mathrm{w} / \mathrm{v}): \mathbf{1 0} \cdot 0, \mathrm{~K}_{2} \mathrm{HPO}_{4} ; \mathbf{1 0} \cdot 0, \mathrm{KH}_{2} \mathrm{PO}_{4}$. Solution $\mathrm{B}$ contained $(\%, \mathrm{w} / \mathrm{v}): 4 \cdot 0, \mathrm{MgSO}_{4} .7 \mathrm{H}_{2} \mathrm{O} ; 0 \cdot 2, \mathrm{NaCl} ; 0 \cdot 2, \mathrm{FeSO}_{4} .7 \mathrm{H}_{2} \mathrm{O} ; 0 \cdot 2$, $\mathrm{MnSO}_{4} \cdot \mathbf{4} \mathrm{H}_{2} \mathrm{O}$.

Production of the inhibitory substances. After $48 \mathrm{hr}$. of incubation at $37^{\circ}$ the fluid which was still present in the bottles of the aerobic-growing organisms was removed and filtered through a Seitz pad. The bacteria which remained on the surface were suspended in a minimal volume of buffered saline solution ( $\mathrm{pH} \mathrm{7 \cdot 4)}$ which just permitted a complete removal of the whole bacterial growth. The bacterial suspensions were exposed for $30 \mathrm{~min}$. to the action of a Raytheon Sonic Vibrator (9 kcyc.), the debris centrifuged down and the supernatant fluids tested for their protein content. All extracts were brought to a dilution which contained $10 \mathrm{mg}$. protein $/ \mathrm{ml}$.

The anaerobic bacteria were removed by centrifugation from their medium after $24 \mathrm{hr}$. of incubation at $37^{\circ}$, resuspended in a small volume of the same medium to give a suspension of $10^{9}$ bacteria $/ \mathrm{ml}$., incubated for $48 \mathrm{hr}$. at $37^{\circ}$, and the supernatant fluids examined for their inhibitory action.

Contact of streptomycin with inhibitors. One-tenth $\mathrm{ml}$. of the final products (the supernatant fluids and the cell extracts) were incubated for $3 \mathrm{hr}$. with $0.9 \mathrm{ml}$. of a streptomycin solution (final streptomycin concentration of $20 \mu \mathrm{g} . / \mathrm{ml}$.).

Assay of activity of the resulting streptomycin solution. After a $3 \mathrm{hr}$. exposure at $37^{\circ} 0.2 \mathrm{ml}$. portions of the solution were transferred to glass cups placed on the surface of a nutrient agar plate. The nutrient agar contained $(\%, \mathrm{w} / \mathrm{v})$ : Bacto peptone, $1 \cdot 0 ; \mathrm{NaCl}, 0 \cdot 5 ; \mathrm{Na}_{2} \mathrm{HPO}_{4}, 0 \cdot 25 ;$ Bovril, $0 \cdot 3$; starch 0.5 ; agar, 2.5 ; (the $\mathrm{pH}$ was adjusted to 8.5 ).

This medium was poured into plates of different sizes with a bacterial suspension to give $5 \times 10^{8}$ vibrios/ml. agar. After incubation for $24 \mathrm{hr}$. an 
iodine solution was poured on the surface of the plates and the diameter of the white zone resulting from the decomposition of starch was measured. A concentration of $20 \mu \mathrm{g}$. streptomycin $/ \mathrm{ml}$. produced an average diameter of $20.8 \mathrm{~mm}$. and by comparison with this standard the antagonist activity of the different preparations was determined (see Plate 1 ).

The reliability of the method used. Figure 1 shows the relationship between $\log$ concentration streptomycin in a range from 2.5 to $20.0 \mu \mathrm{g} . / \mathrm{ml}$. and the diameters of the zones of decomposed starch which appeared as white zones

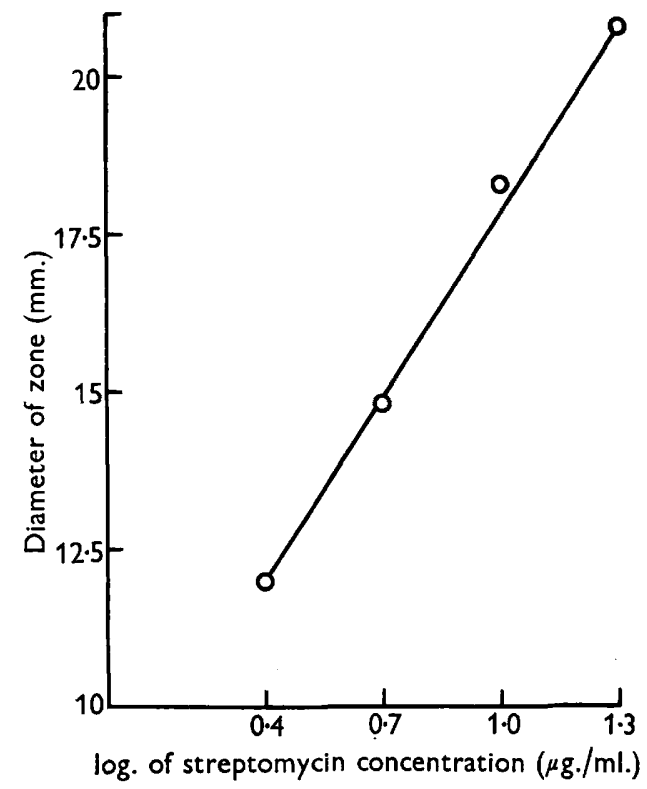

Fig. 1. The diameters of the zones of starch decomposition (mm.) in relation to the logarithms of the streptomycin concentrations.

by treatment of the plates with iodine. The average diameters, for 5,10 and $20 \mu \mathrm{g}$. streptomycin $/ \mathrm{ml}$., determined from 28 repeated examinations, were $14.8,18.3$, and $20.8 \mathrm{~mm}$., respectively, the respective standard deviations were $\pm 0.9, \pm 1 \cdot 13$ and $\pm 1.44 \mathrm{~mm}$. Under these circumstances a decrease of the zone diameter from 20 to $18 \mathrm{~mm}$. should indicate a $50 \%$ and a decrease to about $15 \mathrm{~mm}$. a $75 \%$ loss in activity of streptomycin. On the other hand, there appeared in the presence of $20 \mu \mathrm{g}$. streptomycin $/ \mathrm{ml}$. and dilutions $1 / 32,1 / 16$, $1 / 8,1 / 4$, and $1 / 2$ of an inhibitory preparation of Pseudomonas aeruginosa the following respective diameters of white zones (mm.): 20.8, 18.1, 14.7, 8.8, 0 . According to Fig. 1 the respective concentrations of active streptomycin were exactly $20,10,5,2.5$ and $0 \mu \mathrm{g}$. $/ \mathrm{ml}$. Thus this experiment proved that in a certain range of dilutions the diameters of the zones of starch decomposition were inversely proportional to the logarithm of the concentration of antagonist. 


\section{RESULTS}

\section{Preparations of antagonists of different origins}

Table 1 shows the effects of several antagonistic bacterial products revealed by this method. The most active strains were found in the genus Pseudomonas. Four out of 9 strains effected a complete inactivation, 4 others an inactivation of $75 \%$, and one strain of $50 \%$. The supernatant fluids resulting from

Table 1. Effect of bacterial products on zone of starch decomposition produced by Vibrio comma (Ogawa 40, streptomycin-dependent) in the presence of a standard concentration of $20 \mu \mathrm{g}$. streptomycin $/ \mathrm{ml}$.

\begin{tabular}{|c|c|c|}
\hline \multirow[b]{2}{*}{ Strain tested } & \multicolumn{2}{|c|}{$\begin{array}{l}\text { Diameter of zone of decomposi } \\
(\mathrm{mm} .) \text { in the presence of }\end{array}$} \\
\hline & $\begin{array}{l}\text { Supernatant } \\
\text { fluids }\end{array}$ & $\begin{array}{l}\text { Cell-free } \\
\text { extracts }\end{array}$ \\
\hline Pseudomonas hydrophila & $13 \cdot 0$ & $14 \cdot 0$ \\
\hline P. non-liquefaciens & $14 \cdot 0$ & $15 \cdot 0$ \\
\hline P. fluorescens & $15 \cdot 0$ & $12 \cdot 0$ \\
\hline Pseudomonas sp. from eggs & $15 \cdot 0$ & $15 \cdot 0$ \\
\hline P. aeruginosa & 0 & $\mathbf{0}$ \\
\hline Pseudomonas sp. & $17 \cdot 0$ & $19 \cdot 0$ \\
\hline Pseudomonas sp. $46 / 4$ & 0 & $\mathbf{0}$ \\
\hline Pseudomonas sp. 56/1 & 0 & $\mathbf{0}$ \\
\hline Pseudomonas sp. 84/2 & 0 & $\mathbf{0}$ \\
\hline Vibrio comma (Inaba) & $18 \cdot 0$ & $20 \cdot 0$ \\
\hline$V$. comma (Celebes) & $18 \cdot 5$ & $20 \cdot 0$ \\
\hline V. comma (Ogawa 1$)$ & $19 \cdot 5$ & $20 \cdot 0$ \\
\hline$V$. comma (Ogawa 40) & $19 \cdot 0$ & $20 \cdot 0$ \\
\hline Vibrio sp. & $21 \cdot 0$ & $19 \cdot 0$ \\
\hline Proteus vulgaris $\mathrm{V}_{1}$ & $18 \cdot 0$ & $17 \cdot 5$ \\
\hline P. vulgaris $\mathrm{V}_{2}$ & $18 \cdot 5$ & $18 \cdot 0$ \\
\hline P. morganii $\mathbf{M}_{1}$ & $15 \cdot 0$ & $16 \cdot 5$ \\
\hline P. morganii $\mathbf{M}_{2}$ & $19 \cdot 5$ & $18 \cdot 5$ \\
\hline P. rettgeri $\mathbf{R}_{1}$ & $20 \cdot 0$ & $18 \cdot 0$ \\
\hline P. rettgeri $\mathbf{R}_{2}$ & $18 \cdot 0$ & $18 \cdot 5$ \\
\hline Escherichia coli & $18 \cdot 5$ & $15 \cdot 0$ \\
\hline Klebsiella sp. & $19 \cdot 0$ & $17 \cdot 0$ \\
\hline Shigella flexneri & $20 \cdot 0$ & $16 \cdot 5$ \\
\hline Clostridium parabotulinum $\mathbf{3 7 3 2}$ & - & $14 \cdot 4$ \\
\hline C. welchii 8798 & - & $13 \cdot 5$ \\
\hline C. botulinum & - & $13 \cdot 5$ \\
\hline C. septicum & - & $14 \cdot 5$ \\
\hline C. histolyticum 503 & - & $18 \cdot 0$ \\
\hline Bacillus megaterium & $21 \cdot 0$ & $15 \cdot 0$ \\
\hline B. subtilis & $20 \cdot 0$ & $17 \cdot 0$ \\
\hline Rhodotorula sp. & $15 \cdot 5$ & $20 \cdot 0$ \\
\hline
\end{tabular}

Diameter of the zone of decomposition in the presence of streptomycin $20 \mu \mathrm{g} . / \mathrm{ml}$. without inhibitor was $20.8 \mathrm{~mm}$.

centrifugation of culture fluids showed almost the same degrees of activities as the cell-free extracts obtained after disruption of the organisms by sonic waves. However, the antagonistic actions were not limited to the genus Pseudomonas. Two out of $\mathbf{5}$ vibrios (Inaba and Celebes) showed some 
antagonistic effects, decreasing the activity of streptomycin to about $50 \%$ of it original value. Another group of micro-organisms able to produce inhibitor was found in the genus Proteus. The cell-free extracts of 6 strains decreased the activity of streptomycin to about 50\% and one strain, Proteus morganii even to about $75 \%$.

The extracts obtained by autolysing of 4 clostridia decreased the activity of streptomycin to about $75 \%$ and of Clostridium histolyticum to $50 \%$ of its original value. The supernatant fluids of 3 strains of Enterobacteriaceae (Escherichia coli, Klebsiella sp., Shigella flexneri) exerted a relatively weak effect. However, in the presence of their sonic extracts nearly $75 \%$ of streptomycin was inactivated. The supernatant fluids of two cultures of the genus Bacillus were inactive. However, the cell-free extracts of the same strains decreased the activity of streptomycin by more than $50 \%$. On the other hand, the supernatant fluid of a Rhodotorula sp. showed some antagonistic activity, while its sonic extract was inactive. Table 2 shows results obtained with the products of other micro-organisms which were almost inactive in this test.

Table 2. Starch decomposition by the streptomycin-dependent strain Ogawa 40 in the presence of different inactive or slightly active bacterial products at a standard concentration of $20 \mu \mathrm{g}$. streptomycin $/ \mathrm{ml}$.

\begin{tabular}{|c|c|c|}
\hline \multirow[b]{2}{*}{ Strain tested } & \multicolumn{2}{|c|}{$\begin{array}{l}\text { Diameter of zone of decomposi } \\
(\mathrm{mm} .) \text { in the presence of }\end{array}$} \\
\hline & $\begin{array}{l}\text { Supernatant } \\
\text { fluids }\end{array}$ & $\begin{array}{l}\text { Cell-free } \\
\text { extracts }\end{array}$ \\
\hline Salmonella paratyphi $\mathbf{A}$ & $19 \cdot 0$ & $21 \cdot 0$ \\
\hline S. paratyphi B & $21 \cdot 5$ & $20 \cdot 0$ \\
\hline Serratia marcescens & 18.5 & $\mathbf{2 2 \cdot 0}$ \\
\hline Staphylococcus albus & $20 \cdot 0$ & $18 \cdot 0$ \\
\hline S. aureus & $21 \cdot 0$ & $18 \cdot 0$ \\
\hline Streptococcus faecalis & $17 \cdot 5$ & $20 \cdot 0$ \\
\hline S. lactis & $20 \cdot 5$ & $20 \cdot 0$ \\
\hline Brucella abortus & $18 \cdot 5$ & $18 \cdot 5$ \\
\hline B. melitensis & $18 \cdot 5$ & $19 \cdot 5$ \\
\hline Pasteurella pestis & $20 \cdot 0$ & $18 \cdot 5$ \\
\hline P. pseudotuberculosis & $18 \cdot 0$ & $19 \cdot 0$ \\
\hline Alkaligenes faecalis & $18 \cdot 0$ & $18 \cdot 0$ \\
\hline Saccharomyces sp. & $18 \cdot 0$ & $20 \cdot 0$ \\
\hline Candida albicans & $18 \cdot 0$ & $20 \cdot 0$ \\
\hline
\end{tabular}

Control of the bacterial products for growth-inhibitory activity

In order to avoid false interpretation of the results caused by growthinhibitory bacterial products, we tested the antagonistic products for their antibiotic activity in the absence of streptomycin against the following bacteria: Vibrio comma (Ogawa 1, streptomycin-sensitive) which was the parent strain of the dependent strain Ogawa 40, Bacillus subtilis, Corynebacterium diphtheriae, Escherichia coli, Neisseria catarrhalis, Staphylococcus aureus, Proteus vulgaris, Salmonella typhi, and Streptococcus pyogenes. In addition to the plate method antagonists were added to cultures of Ogawa 40 on the semidefined medium described by Olitzki \& Olitzki (1956), but no inhibition was 
noted when at least $100 \mu \mathrm{g}$. streptomycin $/ \mathrm{ml}$. was present. To avoid false interpretation by an inhibitory effect of the anaerobic medium, streptomycin was brought in contact with this medium before the clostridia were inoculated. No inhibitory effect was observed.

In a final experiment (Table 3) it was shown that under the same experimental conditions as used for demonstrating the antagonism, an increase in concentration of streptomycin above the standard concentration of $20 \mu \mathrm{g} . / \mathrm{ml}$.

Table 3. Effect of increasing streptomycin concentrations on the streptomycin-inhibiting effect of different bacterial preparations

Diameter of zone of decomposition ( $\mathrm{mm}$.) in the

Extract prepared from strain presence of streptomycin $(\mu \mathrm{g} . / \mathrm{ml}$.

Pseudomonas hydrophila
P. non-liquefaciens
P. fluorescens
Pseudomonas sp. from eggs
P. aeruginosa
Pseudomonas sp. $56 / 1$
Vibrio comma (Ogawa 1 )
Proteus vulgaris $\mathrm{V}_{1}$
P. morganii $\mathbf{M}_{1}$
P. rettgeri $\mathbf{R}_{1}$
Escherichia coli
Klebsiella sp.
Shigella flexneri
Clostridium parabotulinum $\mathbf{3 7 3 2}$
C. welchii 8798
C. histolyticum 503
Bacillus megaterium
B. subtilis

\begin{tabular}{lllll}
\hline 20 & 40 & 80 & 160 & 640 \\
$14 \cdot 2$ & 18 & 21 & - & - \\
15 & 18 & $20 \cdot 5$ & - & - \\
$12 \cdot 2$ & 15 & $18 \cdot 5$ & 21 & - \\
15 & $18 \cdot 5$ & 21 & - & - \\
0 & 0 & $8 \cdot 5$ & 15 & 21 \\
0 & 0 & 9 & $15 \cdot 5$ & 21 \\
$19 \cdot 7$ & $20 \cdot 5$ & $20 \cdot 5$ & - & - \\
17 & 20 & $20 \cdot 5$ & - & - \\
10 & 16 & 19 & 21 & - \\
18 & 20 & 21 & - & - \\
$15 \cdot 5$ & 18 & 21 & - & - \\
19 & $20 \cdot 5$ & 21 & - & - \\
17 & 20 & 21 & - & - \\
15 & $18 \cdot 5$ & 20 & - & - \\
15 & 19 & $20 \cdot 5$ & - & - \\
18 & 19 & 20 & - & - \\
15 & $18 \cdot 5$ & 21 & - & - \\
16.5 & 19 & 21 & - & -
\end{tabular}

Remarks. Diameter of the zone of decomposition in the presence of $20 \mu \mathrm{g}$. streptomycin $/ \mathrm{ml}$. without inhibition was $20.7 \mathrm{~mm}$.

produced less antagonism than at the lower streptomycin concentration. The highly active preparations of Pseudomonas aeruginosa required for the complete disappearance of the antagonism $640 \mu \mathrm{g}$. streptomycin $/ \mathrm{ml}$., while with relatively weak inhibitors from Enterobacteriaceae and Bacillaceae the inhibiting effect disappeared at $40-80 \mu \mathrm{g}$ streptomycin $/ \mathrm{ml}$. These results confirm the observations made in the former experiments where a preparation of Pseudomonas aeruginosa diluted 1/16 inactivated $10 \mu \mathrm{g}$. streptomycin $/ \mathrm{ml}$. It was therefore expected that the undiluted preparation should inactivate at least $160 \mu \mathrm{g}$. streptomycin $/ \mathrm{ml}$.; Table 3 confirms this expectation. In the presence of the preparation from Pseudomonas aeruginosa and $160 \mu \mathrm{g}$. streptomycin $/ \mathrm{ml}$. there appeared a zone of diameter of $15 \mathrm{~mm}$., indicating that only $5 \mu \mathrm{g}$. streptomycin $/ \mathrm{ml}$. remained active, and that $155 \mu \mathrm{g} . / \mathrm{ml}$. had been inactivated. On the other hand, it was expected that preparations which even when undiluted inactivated only 10 or $15 \mu \mathrm{g}$. streptomycin $/ \mathrm{ml}$. would not give any inhibitory effect in the presence of $80 \mu \mathrm{g}$. streptomycin $/ \mathrm{ml}$. Table 3 confirms this expectation for all the weakly active preparations. 


\section{REFERENCES}

Light воwn, J. W. (1950). An antagonist of dihydrostreptomycin and streptomycin produced by Pseudomonas pyocyanea. Nature, Lond. 166, 356.

Lightвоwn, J. W. (1954). An antagonist of streptomycin and dihydrostreptomycin produced by Pseudomonas aeruginosa. J. gen. Microbiol. 11, 477.

Olitzki, A. L. \& OLITzki, Z. (1955). Pathogenicity and antigenicity of streptomycin dependent mutants of Vibrio comma (types: Inaba and Ogawa). Exp. Med. Surg. 13, 332.

Ourtzki, A. L. \& Ouitzki, Z. (1956). Nutritional requirements of a streptomycindependent Vibrio comma (Ogawa) and its use for the quantitative determination of streptomycin in urine and serum. Antibiotic Med. 2, 317.

Ourtzki, A. L. \& OLITzKI Z. (1957). The action of streptomycin on the amylase activity of Vibrio comma. Giorn. Microbiol. 3, 109.

Sulitzeanu, D. \& Olitzki, A. L. (1955). Use of a streptomycin dependent strain of Vibrio comma for quantitative assay of streptomycin. Exp. Med. Surg. 13, 394.

\section{EXPLANATION OF PLATE}

Plate 1. [Natural size]

(1) $2.5 \mu$ g. streptomycin $/ \mathrm{ml}$. (2) $5 \cdot 0 \mu \mathrm{g}$. streptomycin $/ \mathrm{ml}$. (3) $10 \cdot 0 \mu \mathrm{g}$. streptomycin $/ \mathrm{ml}$. (4) $20 \cdot 0 \mu \mathrm{g}$. streptomycin $/ \mathrm{ml}$. (5) $20 \cdot 0 \mu \mathrm{g}$. streptomycin/ml. +extract of Pseudomonas sp. (6) $20.0 \mu$ g. streptomycin/ml. + extract of Bacillus subtilis. (7) $20 \cdot 0 \mu \mathrm{g}$. streptomycin/ml. + extract of Proteus morganii. (8) $20.0 \mu \mathrm{g}$. streptomycin/ml. + extract of Vibrio comma, strain Ogawa 1.

(Received 30 June 1958) 
Journal of General Microbiology, Vol. 20, No. 1

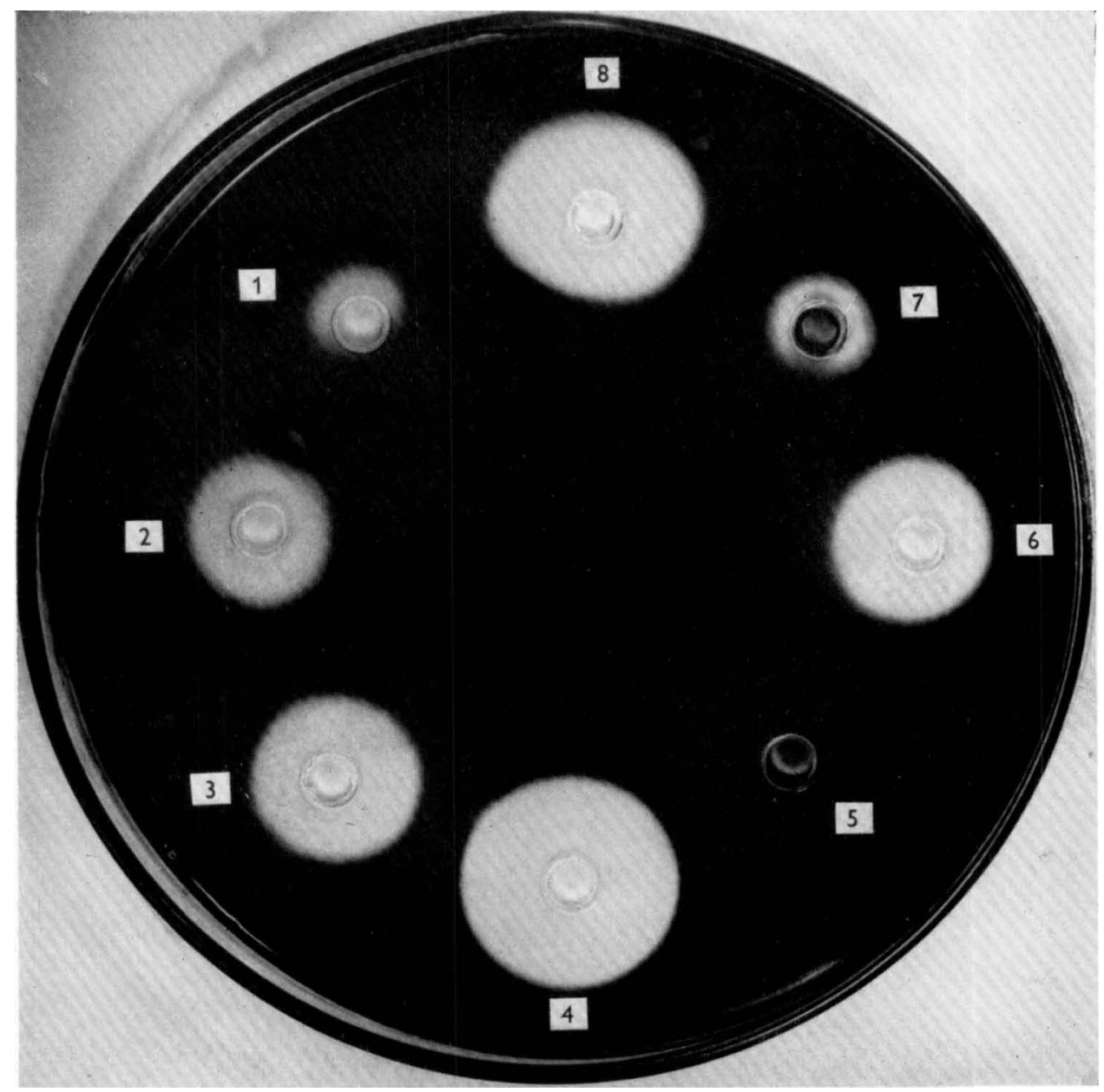

A. L. Olitzki \& D. Godinger-Streptomycin inhibitors. Plate 1

(Facing p. 60) 